\title{
KINETICS OF CASEIN HYDROLYSIS BY PEPTIDASE FROM Bacillus thuringiensis var. israelensis
}

\author{
O. V. SEVASTYANOV ${ }^{1}$, YU. A. SHESTERENKO ${ }^{1}$, A. A. RYZHAK ${ }^{1}$, \\ I. I. ROMANOVSKA ${ }^{1}$, N. A. DZIUBLIUK ${ }^{2}$, L. D. VARBANETS ${ }^{2}$
}

\author{
${ }^{1}$ A. V. Bogatsky Physico-Chemical Institute, \\ National Academy of Sciences of Ukraine, Odesa; \\ ${ }^{2}$ Danylo Zabolotny Institute of Microbiology and Virology, \\ National Academy of Sciences of Ukraine, Kyiv; \\ e-mail: romairina@gmail.com
}

Received: 25 October 2018; Accepted: 14 March 2019

The kinetics of enzyme reaction is generally studied using the Michaelis-Menten equation and various methods of its linearization. Each method has its advantages and drawbacks, so their comparison for determining the kinetics of new enzymes action is topical. The aim of this work was to study the kinetics of casein hydrolysis catalyzed by new peptidase from Bacillus thuringiensis var. israelensis IMB B-7465 using several methods of enzyme activity assessment and Michaelis-Menten equation linearization. The satisfactory agreement between kinetic constants values obtained by the methods of Lineweaver-Burk, Hanes, Eadie-Hofstee, Cornish-Bowden-Eisenthal was established. The Lineweaver-Burk method was shown to be optimal for determining $K_{m}$ and $V_{\max }$ of casein hydrolysis. Estimation of caseinolytic activity with the use of ortho-phthalic dialdehyde allowed more accurate $V_{\max }$ determination compared to the use of Anson and Kunitz methods.

Ke y w o r d s: casein hydrolysis, kinetics, linearization methods, activity determination, peptidase, Bacillus thuringiensis var. israelensis.

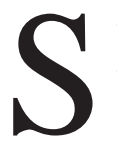

tudying new enzymes suggests the investigation of important enzyme characteristics such as catalytic property, affinity for substrates and mechanism of action. The main factors that influence the enzyme reaction rate are substrate concentration and chemical nature, medium $\mathrm{pH}$, temperature and the presence of inhibitors. Therefore, the study of the kinetics of enzymatic reactions is important.

The steady-state enzyme kinetics has been studied with the use of the Michaelis-Menten equation and various forms of its linearization, such as Lineweaver-Burk, Hanes, Eadie-Hofstee, CornishBowden-Eisenthal methods [1-5]. Various results were obtained regarding the best linearization method in kinetics studies of protease-catalyzed casein hydrolysis. Devi S.G. et al. in their research of alkaline protease from activated sludge of a tannery, considered the Eadie-Hofstee method to be optimal, while the Lineweaver-Burk equation resulted in sig- nificant standard errors [3]. Yoshii et al., studying the kinetics of two proteases, obtained similar values for the kinetic constants, determined by the LineweaverBurk and Hanes methods. However, the standard errors were slightly lower in the later [4]. Verma M.K. et al. showed, that the kinetic parameters, determined by the Hanes and Lineweaver-Burk methods had closer values and were 2-fold lower than determined by Eadie-Hofstee one [5]. Thus, comparing various linearization methods for the study of the kinetics of new proteases is important for obtaining most accurate kinetic constants.

Methods for the assessment of the proteolytic enzyme activity can be divided into two main groups: with low or high molecular mass substrates [6]. The method to be chosen depends on the objective of a study and the protease specificity; besides, various methods differ in accuracy, measurement units and duration of research.

(C) 2019 Sevastyanov O. V. et al. This is an open-access article distributed under the terms of the Creative Commons Attribution License, which permits unrestricted use, distribution, and reproduction in any medium, provided the original author and source are credited. 
This work aimed to determine the kinetic parameters of casein hydrolysis, catalyzed by new peptidase from $B$. thuringiensis var. israelensis IMB B-7465, using different linearization of the Michaelis-Menten equation and three approaches for the enzyme activity assessment.

It was previously shown [7], that the studied peptidase is metal-dependent serine peptidase with the optimum $\mathrm{pH} 10.0$ and temperature $50^{\circ} \mathrm{C}$. It hydrolyzes native protein substrates such as elastin, collagen, fibrin, fibrinogen, casein, gelatin, as well as chromogenic substrates: S2238 (H-D-Phe-PipArg-pNA), S2251 (D-Val-Leu-Lys-pNA), S2302 (HD-Pro-Phe-Arg-pNA), S1040 (Glp-Ala-Ala-LeupNA).

\section{Materials and Methods}

In our work we studied the Bacillus thuringiensis var. israelensis strain IMB B-7465 obtained from the water area of Snake Island (Black Sea) and kindly provided by the staff of the Department of Microbiology, Virology and Biotechnology of Odessa I.I. Mechnikov National University. The strain is registered in the Culture Depository of D.K. Zabolotny Institute of Microbiology and Virology, NAS of Ukraine, No. IMB-7465 as a collagenolytic peptidase producing bacteria [8].

The strain was cultivated in an incubation medium of the following composition (g/l): $\mathrm{KH}_{2} \mathrm{PO}_{4}-$ 1.6; $\mathrm{MgSO}_{4} \cdot 7 \mathrm{H}_{2} \mathrm{O}-0.75 ; \mathrm{ZnSO}_{4} \cdot 7 \mathrm{H}_{2} \mathrm{O}-0.25$; $\left(\mathrm{NH}_{4}\right)_{2} \mathrm{SO}_{4}-0.5$; maltose -1.0 ; gelatin -10.0 ; yeast autolysate -0.15 ; $\mathrm{pH}$ 6.5-6.7 on a shaking platform at $250 \mathrm{rpm}$ for $24 \mathrm{~h}$, at $28^{\circ} \mathrm{C}$ [9]. Erlenmeyer flasks $(750 \mathrm{ml})$ containing $200 \mathrm{ml}$ of the incubation medium were seeded with inoculum in the middle of the exponential phase growth on the same medium.

Peptidase of $B$. thuringiensis var. israelensis IMB B-7465 was isolated from the supernatant after centrifugation of the culture medium (5000 g, $30 \mathrm{~min}$ ) and by ammonium sulfate (60\% saturation) precipitation. The precipitate was collected by centrifugation (5000 g, $30 \mathrm{~min}$ ), then dissolved in $0.01 \mathrm{M}$ Tris- $\mathrm{HCl}$ buffer $(\mathrm{pH} 7.5)$ and applied on a column $(2.5 \times 40 \mathrm{~cm})$ with a TSK DEAE 650 anion exchanger (M) (Toyosoda, Japan). The proteins were eluted with the same buffer in the $\mathrm{NaCl}$ gradient from 0 to $1 \mathrm{M}$ (flow rate $0.5 \mathrm{ml} / \mathrm{min}$ ). Protein fractions with caseinolytic activity were combined and applied to a column $(2.5 \times 40 \mathrm{~cm})$ with a neutral TSKgel, Toyopearl HW-55 (F-grade) (Toyosoda, Japan). Elution was performed with the same buffer (flow rate $0.85 \mathrm{ml} / \mathrm{min}$ ).
The molecular mass of the purified native enzyme was determined by size-exclusion chromatography on a column $(1.5 \times 25 \mathrm{~cm})$ with Sepharose $6 \mathrm{~B}$ (Pharmacia, Sweden), equilibrated with $0.01 \mathrm{M}$ Tris$\mathrm{HCl}$ buffer ( $\mathrm{pH}$ 7.5). Enzyme solution (1 ml) was applied on the column. Elution was performed with the same buffer (flow rate $0.3 \mathrm{ml} / \mathrm{min}$ ). To determine the molecular mass, a calibration curve was plotted using marker proteins (Pharmacia, Sweden): bovine serum albumin (67.0 kDa), proteinase K (28.9 kDa), trypsin (24.0 kDa), lysozyme (14.5 kDa).

Denaturing electrophoresis (SDS-PAGE) was performed by the Laemmli method [10]. The studied enzyme preparation was dissolved in a sample buffer $(0.5 \mathrm{M}$ Tris- $\mathrm{HCl}$ with 2-mercaptoethanol, $\mathrm{pH}$ 8.8) containing $10 \%$ sodium dodecyl sulfate, $20 \%$ glycerol and $0.001 \%$ bromophenol blue), then boiled for $1 \mathrm{~min}$, and applied to a gel $(50-100 \mu \mathrm{g}$ per well). Electrophoresis was performed in a 5\% stacking and $12 \%$ separating acrylamide gels with constant power supply $30 \mathrm{~mA}$. After electrophoresis, the gel was stained with Coomassee G-250. The following protein markers were used (Pharmacia, Sweden): bovine serum albumin (67.0 kDa), ovalbumin $(43.0 \mathrm{kDa})$, carbonic anhydrase $(30.0 \mathrm{kDa})$, a soya bean trypsin inhibitor from soya (20.0 kDa), $\alpha$-lactalbumin (14.4 kDa).

During purification, the total peptidase activity was measured by the modified Anson assay [11], based on the quantitative determination of tyrosine formed during casein hydrolysis under the peptidase activity. The culture medium supernatant $(0.5 \mathrm{ml})$ and a $1 \%$ casein solution $(0.5 \mathrm{ml})$ were added to the test tube. The control tube contained the culture medium supernatant $(0.5 \mathrm{ml})$ and a $4 \%$ solution of trichloroacetic acid (TCA) $(2 \mathrm{cml})$. The samples were incubated on a water bath at $37^{\circ} \mathrm{C}$ for $30 \mathrm{~min}$, and then $2 \mathrm{ml}$ of $4 \%$ trichloroacetic acid (TCA) solution was added to the test tube. The tubes were kept at room temperature for $20 \mathrm{~min}$ and then centrifuged (10,000 g, $5 \mathrm{~min}) .2 .5 \mathrm{ml}$ of $0.5 \mathrm{M} \mathrm{Na}_{2} \mathrm{CO}_{3}$ solution and $0.5 \mathrm{ml}$ of diluted Folin's reagent (1:3) were added to $0.5 \mathrm{ml}$ of the supernatant, and the mixture was kept at room temperature for $20 \mathrm{~min}$. The cleavage products were determined at $670 \mathrm{~nm}$ on spectrophotometer SF-26. The ability of the enzyme to convert casein into non-precipitating TCA-form in an amount, corresponding to $1 \mu \mathrm{mol}$ of tyrosine for $1 \mathrm{~min}$ at $37^{\circ} \mathrm{C}$, was taken as an activity unit.

The total protein level was determined by the modified Lowry assay (Hartree-Lowry method) [12]. Caseinolytic activity was determined by the spectro- 
photometric Kunitz method at $280 \mathrm{~nm}$ [13], by the modified Anson method with the Folin-Ciocalteu's reagent [11], and by determining the amino groups released during proteolysis, using $o$-phthaldialdehyde (OPA) [14]. The latter method was modified by increasing the reagent concentration (4-fold) in $1.0 \mathrm{M} \mathrm{H}_{3} \mathrm{BO}_{3} / \mathrm{NaOH}$ buffer ( $\mathrm{pH}$ 9.2). This modification enabled us to significantly improve the sensitivity of the method.

The kinetics of casein hydrolysis in the presence of isolated peptidase was studied at $37{ }^{\circ} \mathrm{C}$ in $0.017 \mathrm{M}$ Na-phosphate buffer, $\mathrm{pH} 7.5$, by measuring the initial rates of the substrate hydrolysis. The amount of enzyme was $12.5 \mu \mathrm{g}$ of protein. $K_{\mathrm{M}}$ and $V_{\max }$ values were determined within the ascending part of the curve (5 points) relating the initial reaction rate and the substrate concentration. The data obtained were linearized by Hanes, LineweaverBurk, Eadie-Hofstee, Cornish-Bowden-Eisenthal methods [15]. The chosen conditions were for a substrate conversion of no more than $5 \%$ when using the lowest enzyme concentration.

Casein concentration range was 0.31-10.0 g/l. Statistical data analysis was performed using Statistica software with the implementation of Student's $t$-test. The results were considered significant at $P<0.05$. To calculate the standard errors of the kinetic constants, first we calculated the value and standard errors of the linear regression coefficients of the ascending part of the kinetic curve, then the $K_{\mathrm{M}}$ and $V_{\max }$ values and their standard errors were calculated [16].

\section{Results and Discussion}

Peptidase from $B$. thuringiensis var. israelensis IMB B-7465 was isolated by multistep purification using classic methods of protein chemistry: fractionation of the culture supernatant with ammonium sulfate (60\% saturation), ion-exchange chromatography and exclusion chromatography. It was shown (Fig. 1), that when separating the complex enzyme preparation using ion-exchange chromatography with a $\mathrm{NaCl}$ gradient from 0 to $1 \mathrm{M}$ on a column with an anion exchanger TSK Toyopearl DEAE 650 $(\mathrm{M})$, there was one major peak of peptidase with caseinolytic activity (No. 1) at $0.1 \mathrm{M} \mathrm{NaCl}$. This allowed us to remove some protein contaminants from the enzyme preparation.

Isolated fraction 1 was analyzed using exclusion chromatography on TSK Toyopearl HW-55 (Fgrade). The studied peptidase was detected in fraction 2 when $0.01 \mathrm{M}$ Tris-HCl buffer ( $\mathrm{pH} 7.5$ ) was used (Fig. 2).

The homogeneity of the enzyme from $B$. thuringiensis var. israelensis IMB B-7465 and its subunit structure were confirmed by SDS-PAGE (Fig. 3). To

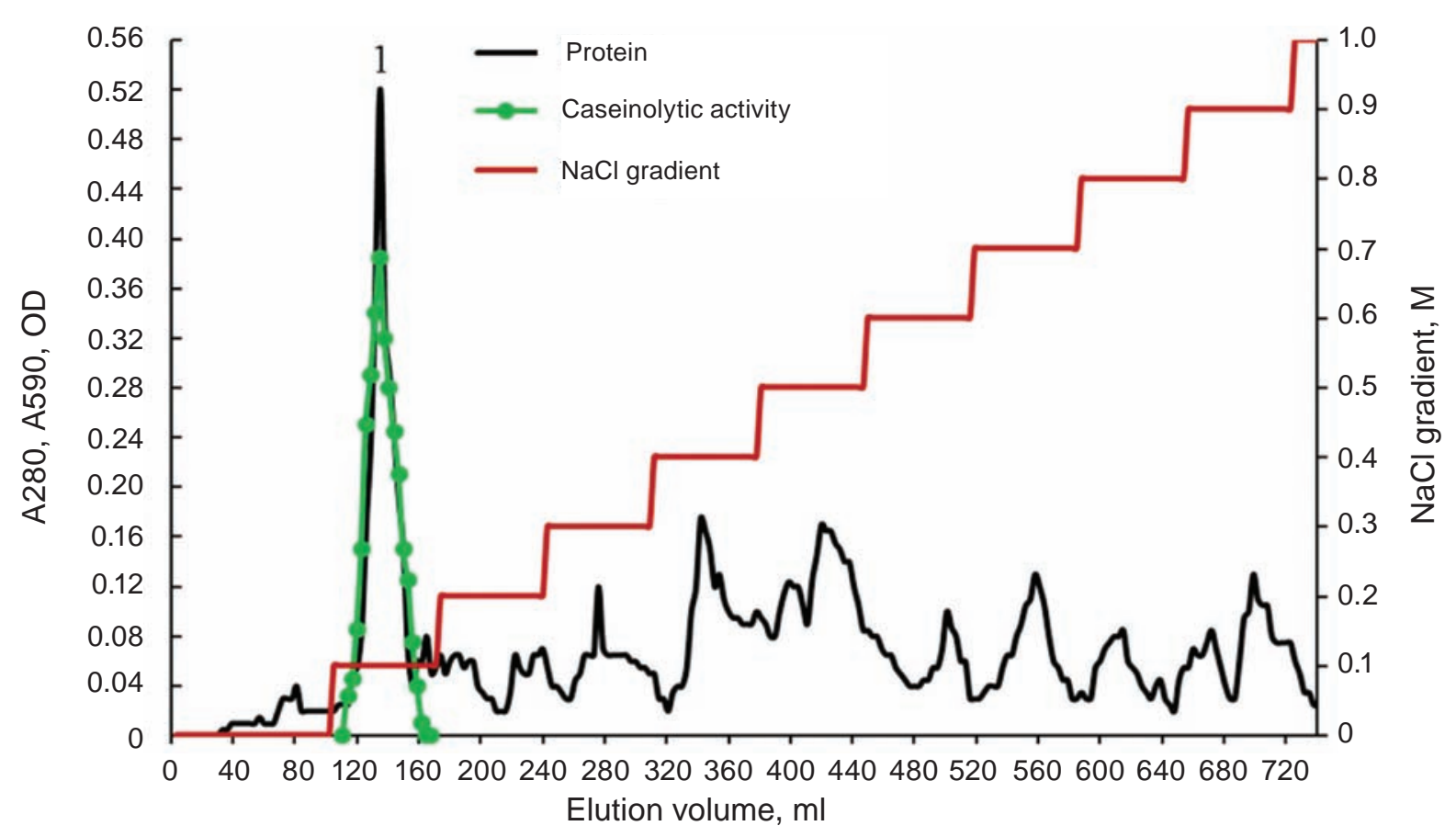

Fig. 1. Elution profile of the complex enzyme preparation from B. thuringiensis var. israelensis IMB B-7465 on TSK Toyopearl DEAE 650 (M) with step NaCl gradient 


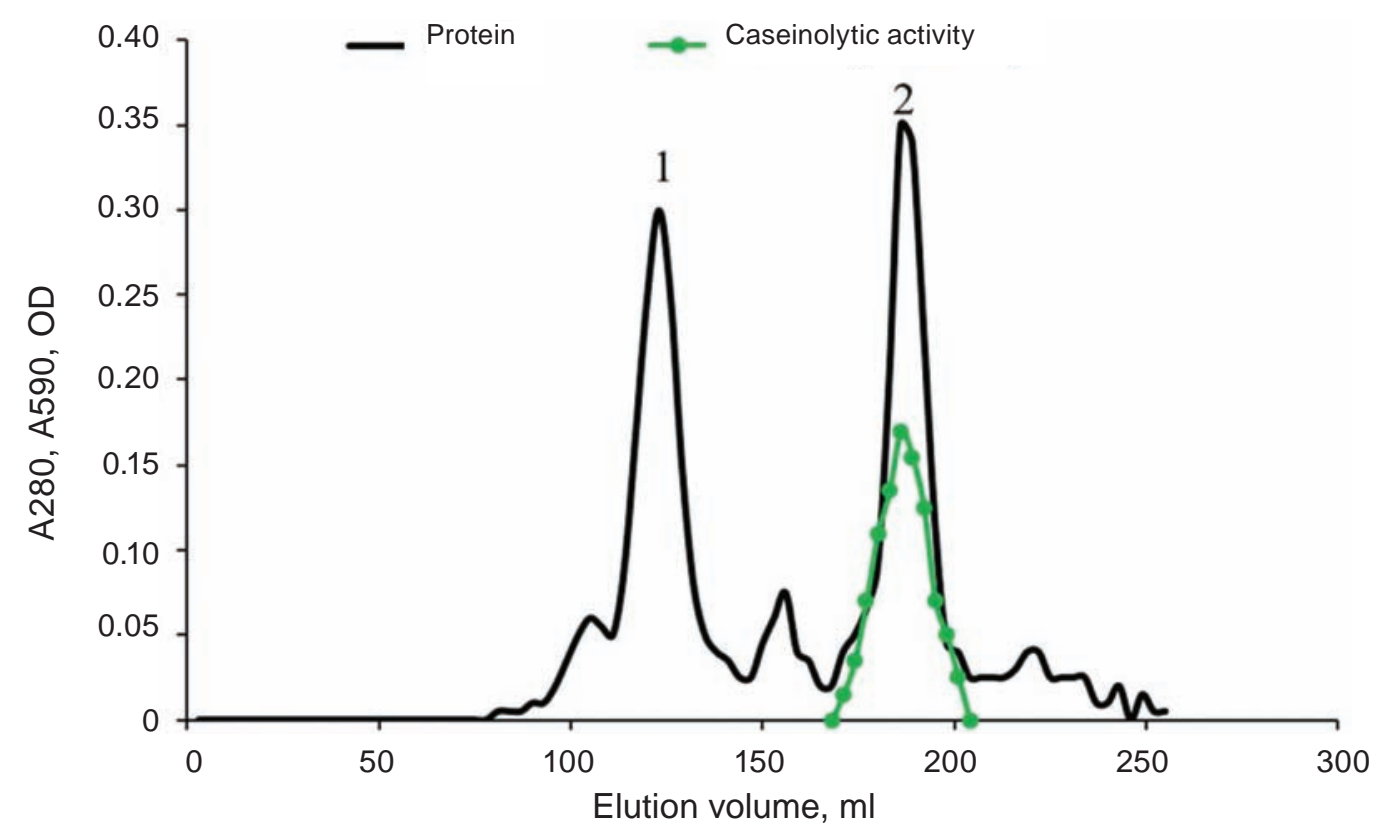

Fig. 2. Elution profile of fraction 1 of the complex enzyme preparation from B. thuringiensis var. israelensis IMB B-7465 on TSK Toyopearl HW-55

I

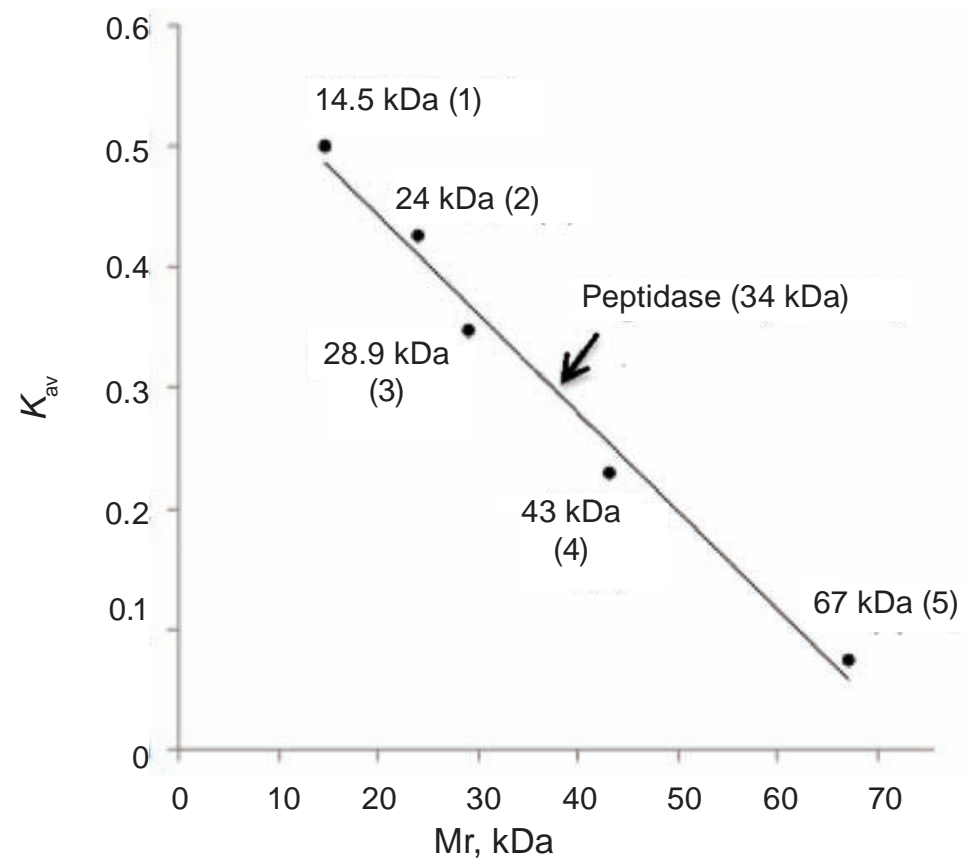

II

$\boldsymbol{b}$

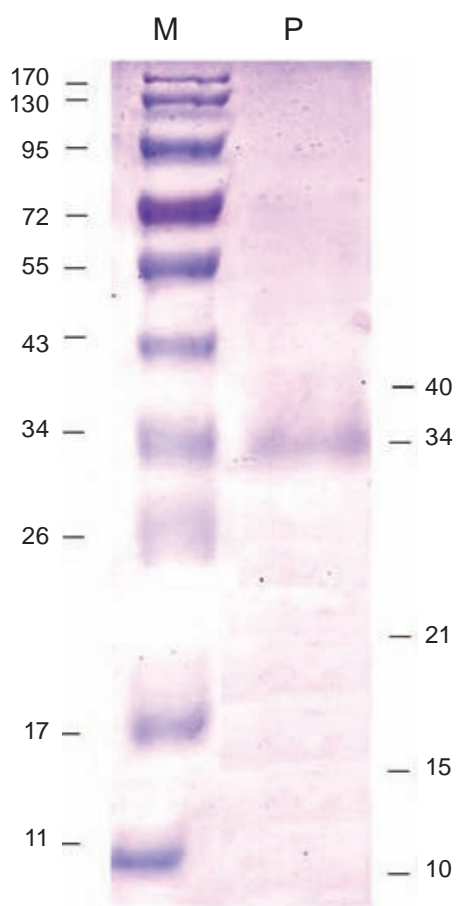

Fig. 3. Determination of the molecular mass of peptidase from B. thuringiensis var. israelensis IMB B-7465 in native (I) and denaturing (SDS-PAGE) (II) conditions: $\boldsymbol{a}$ - size exclusion chromatography on Sepharose $6 B$ (calibration plot); $K_{a v}$ - distribution coefficient; protein markers: lysozyme (1), trypsin (2), proteinase $K$ (3), peroxidase (4), bovine serum albumin (5); $\boldsymbol{b}$-SDS-PAGE $M$ - protein markers; $P$ - peptidase from $B$. thuringiensis var. israelensis IMB B-7465 
determine the molecular mass, we used native and denaturing conditions, in particular, analytical exclusion chromatography on Sepharose 6B and SDSPAGE. The column was calibrated with the protein molecular mass markers. The partition coefficient $\left(K_{\mathrm{av}}\right)$ was calculated as described in [17].

Analysis under native and denaturing conditions showed, that the molecular mass of the peptidase from $B$. thuringiensis var. israelensis IMB B-7465 is $\sim 34 \mathrm{kDa}$ (Fig. 3).

A purified preparation of new peptidase (34 kDa) with a total proteolytic activity of $0.21 \mathrm{U} /$ $\mathrm{ml}$ was isolated from $B$. thuringiensis var. israelensis IMB B-7465 [7].

In our work, we studied the kinetics of casein hydrolysis catalyzed by peptidase from $B$. thuringiensis var. israelensis IMB B-7465 (Fig. 4).

At relatively low substrate concentrations, the reaction rate increased proportionally. When substrate concentration increased, the rate value approached its limit, and then began to decrease. That is, in the certain casein concentration range, the enzyme is inhibited by the substrate.

The kinetic constants were measured within the ascending part of the curve relating the initial reaction rate and the substrate concentration. The obtained data were then linearized.

A comparative analysis of the linearization methods of the Michaelis-Menten equation revealed that $K_{\mathrm{m}}$ parameters, obtained for the selected methods of the enzyme activity assay (Kunitz method, modified Anson method, $\mathrm{NH}_{2}$-groups determination with OPA reagent) using Hanes plot (Fig. 5) have similar values (Table 1).

The obtained $K_{\mathrm{m}}$ values are quite low compared to most of microbial proteases (0.3-19.2 g/l) $[1,3,18,19]$.

The $V_{\max }$ value, determined with the OPA method, was 1.7-fold greater than that with modified Anson method (Table 1). The data obtained indicate that not all the substrate fragments, generated during hydrolysis, contain tyrosine or other aromatic amino acids, which react with the Folin-Ciocalteu's reagent (when using Anson assay). However, almost all amino acids or peptides react with OPA. In the Kunitz method, $V_{\max }$ value is measured in relative proteolytic units. Therefore, it cannot be compared with the other two methods for the caseinolytic activity assay.

For the Hanes plot, high degree approximation coefficients were obtained $\left(\mathrm{R}^{2}=0.999\right)$; however, the standard errors of $K_{\mathrm{m}}$ values were fairly high (Table 1).

A satisfactory agreement between the $K_{\mathrm{m}}$ and $V_{\max }$ parameters (Fig. 6, Table 2) was observed, when using the Lineweaver-Burk method, compared to the Hanes method. The $V_{\max }$ values measured using the OPA method for enzyme assay also found to be greater than determined by the Anson method.

The Lineweaver-Burk method demonstrated slightly lower approximation coefficients (0.9770.984) compared to the Hanes method; but with significantly lower standard errors of $K_{\mathrm{m}}$, (for the OPA
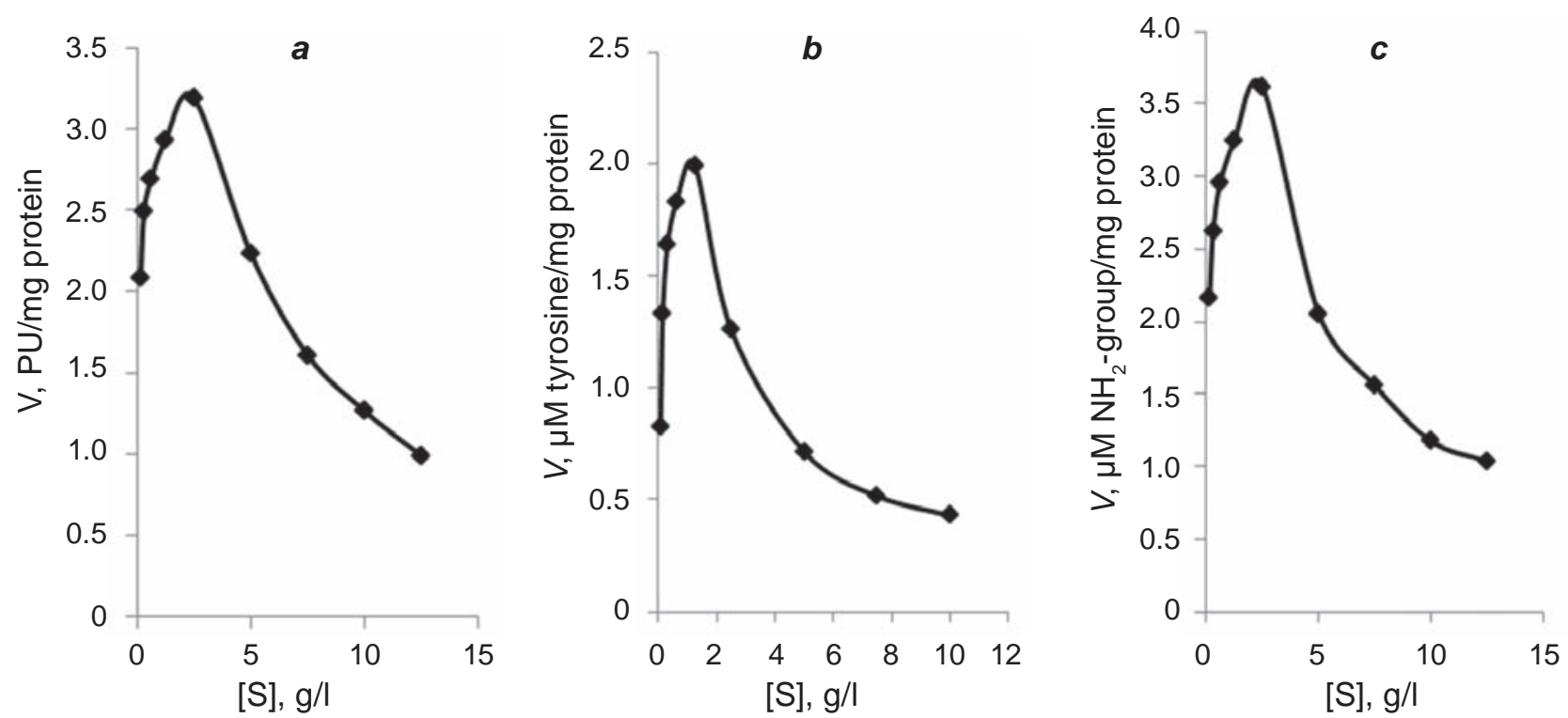

Fig. 4. Kinetics of casein hydrolysis catalyzed by isolated peptidase (proteolytic activity by Kunitz method (a), modified Anson method (b), OPA method (c)) 

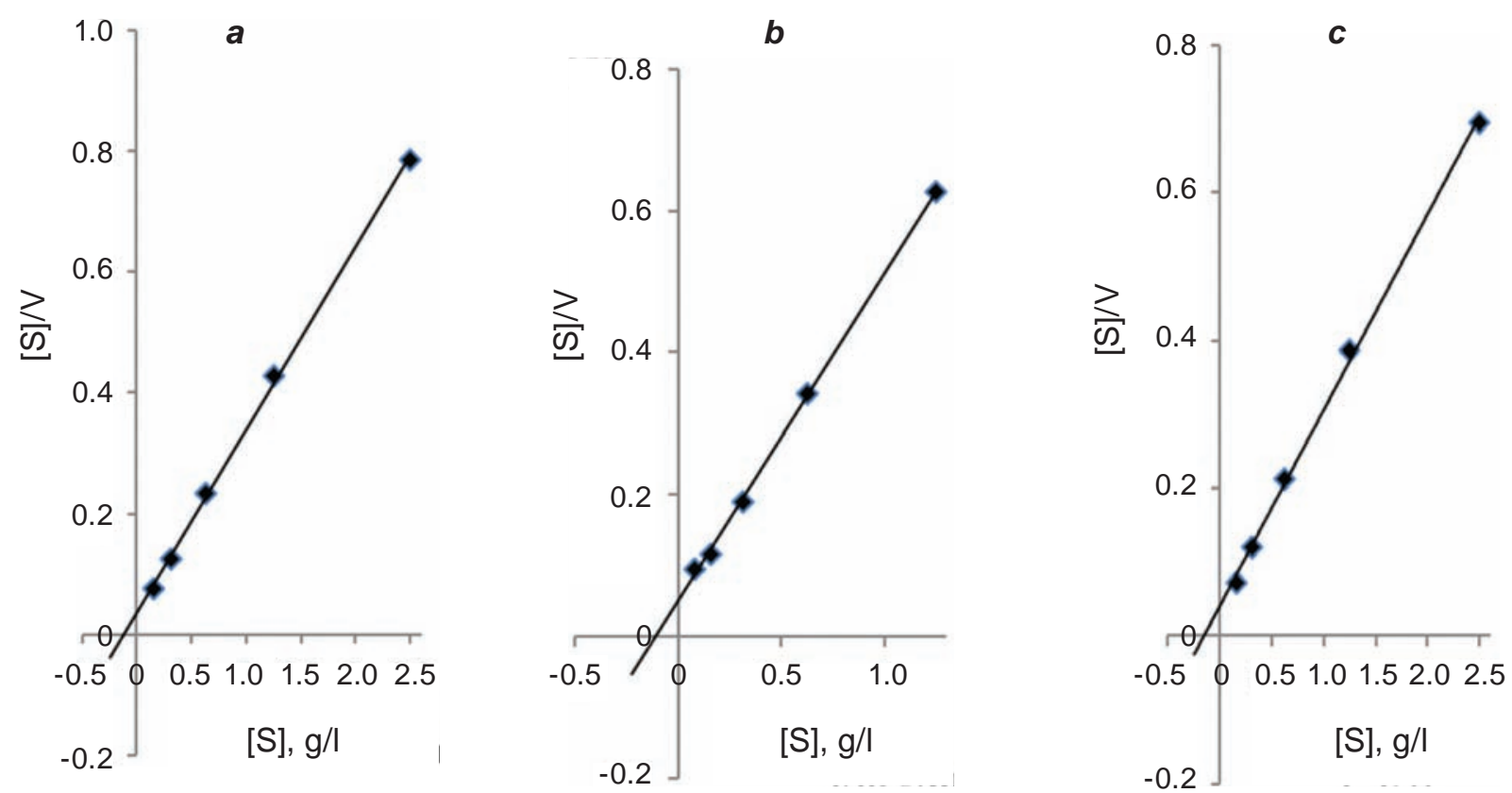

Fig. 5. Determination of the kinetic parameters of casein hydrolysis catalyzed by peptidase by Hanes plot (proteolytic activity by Kunitz method (a), modified Anson method (b), OPA method (c))

Ta ble 1. Kinetic parameters of casein hydrolysis, catalyzed by peptidase from Bacillus thuringiensis, determined by the Hanes method

\begin{tabular}{l|c|c|c}
\hline \multicolumn{1}{c|}{$\begin{array}{c}\text { Caseinolytic } \\
\text { activity assay }\end{array}$} & $K_{\mathrm{m}}, \mathrm{g} / \mathrm{l}$ & $V_{\max }$ & $\mathrm{R}^{2}$ \\
\hline Kunitz method & $0.119 \pm 0.027$ & $3.31 \pm 0.06, \mathrm{PU} / \mathrm{mg}$ protein & 0.999 \\
Modified Anson method & $0.111 \pm 0.012$ & $2.17 \pm 0.03, \mu$ mol tyrosine/mg protein per min & 0.999 \\
OPA method & $0.151 \pm 0.033$ & $3.77 \pm 0.09, \mu \mathrm{mol} \mathrm{NH}_{2}$-group/mg protein per min & 0.999 \\
\hline
\end{tabular}

and Kunitz methods) and relatively low errors of $V_{\max }$ values.

The kinetic constants $K_{\mathrm{m}}$ and $V_{\max }$ obtained by Eadie-Hofstee method also were close to the values, determined by other linearization methods (Fig. 7, Table 3).

However, when using the Eadie-Hofstee method, we obtained low approximation coefficients (0.950-0.956) and comparable values of standard errors for kinetic parameters, obtained by the Lineweaver-Burk method.

The obtained kinetic data were analyzed by the Cornish-Bowden-Eisenthal method. The results were checked for belonging to one experimental sample using the "V" criterion and for normal distribution. The calculated ratios of the asymmetry and excess to their standard errors were below 3 , that is, the data are normally distributed. Therefore, they could be processed by Student's test. The $K_{\mathrm{m}}$ values, obtained for three methods of caseinolytic activity assay, were found to have close values (Table 4). However, the standard errors of $K_{\mathrm{m}}$ constants, when using the OPA and Kunitz methods for the enzyme activity assays, were greater, compared to those by Lineweaver-Burk.

Thus, in our work, we studied the kinetics of casein hydrolysis catalyzed by a new peptidase (34 kDa) from Bacillus thuringiensis var. israelensis IMB B-7465. A satisfactory agreement between values of the kinetic constants obtained by different linearization methods of the Michaelis-Menten equation was found. In our study, the Lineweaver-Burk method was shown to be optimal for determining the kinetic parameters, as it is characterized by the lowest standard errors of $K_{\mathrm{m}}$ and $V_{\max }$ values. The advantage of the OPA method of the enzyme activity assay over other tested methods is the interaction with almost all products of proteolysis, which enables to determine the $V_{\max }$ constants more accurately. 

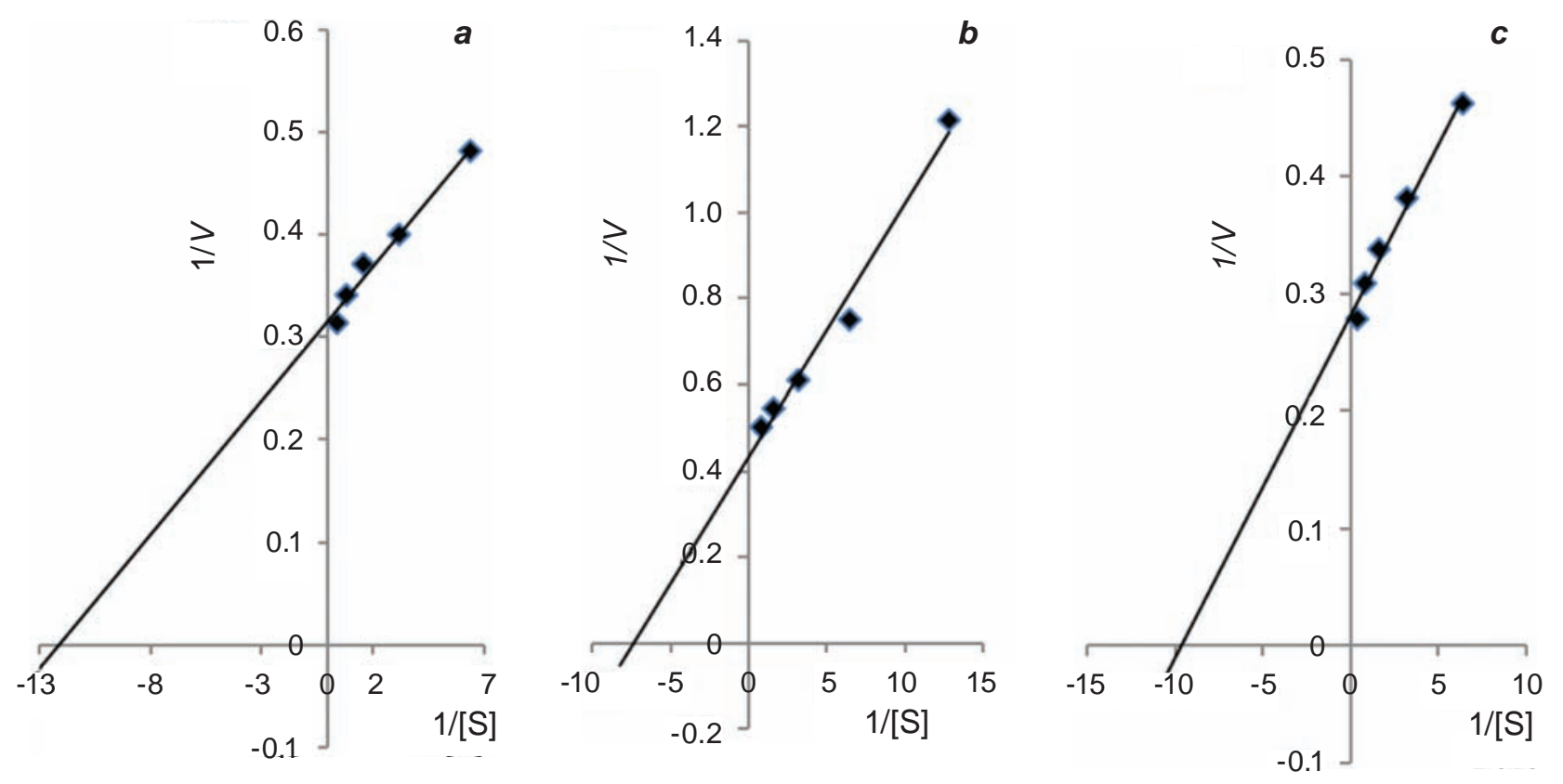

Fig. 6. Determination of kinetic parameters of casein hydrolysis, catalysed by peptidase, by the LineweaverBurk plot (proteolytic activity by the Kunitz method (a), modified Anson method (b), OPA-method (c))
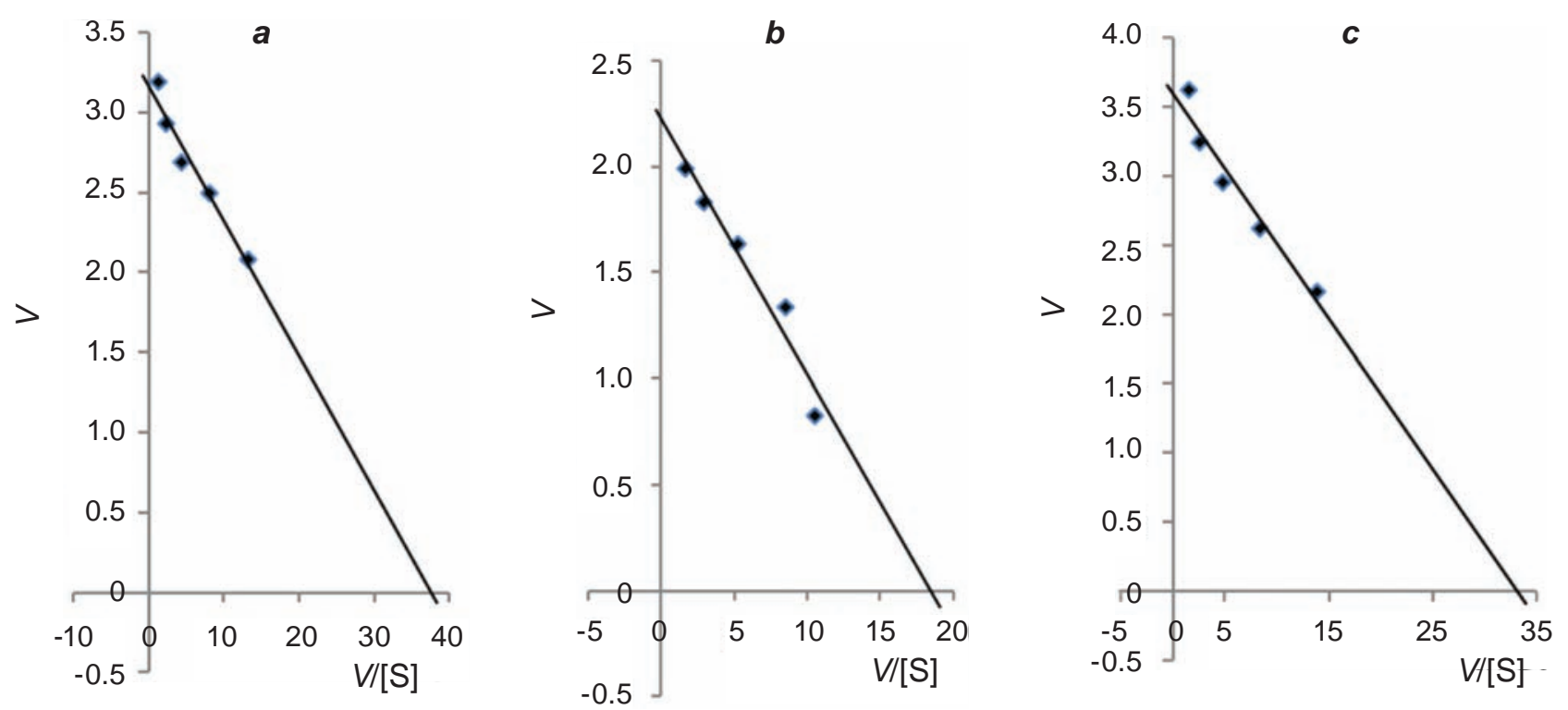

Fig. 7. Determination of the kinetic parameters of casein hydrolysis, catalyzed by peptidase, by the EadieHofstee method (proteolytic activity according to the Kunitz method (a), modified Anson method (b), OPA method (c))

The Bacillus thuringiensis var. israelensis strain IMB B-7465 was obtained from the water area of Snake Island (Black Sea) and kindly provided by the staff of the Department of Microbiology, Virology and Biotechnology of Odessa I.I. Mechnikov National University.

We would like to express our sincere gratitude to PhD V.O. Chernyshenko (Department of Protein
Structure and Function, Palladin Institute of Biochemistry, NASU) for the assistance in performing SDS-PAGE.

Conflict of interest. Authors have completed the Unified Conflicts of Interest form at http:// ukrbiochemjournal.org/wp-content/uploads/2018/12/ coi_disclosure.pdf and declare no conflict of interest. 
Ta ble 2. Kinetic parameters of casein hydrolysis, catalyzed by peptidase from Bacillus thuringiensis, determined by Lineweaver-Burk

\begin{tabular}{|c|c|c|c|}
\hline $\begin{array}{l}\text { Caseinolytic } \\
\text { activity assay }\end{array}$ & $K_{\mathrm{m}}, \mathrm{g} / \mathrm{l}$ & $V_{\max }$ & $\mathrm{R}^{2}$ \\
\hline Kunitz method & $0.082 \pm 0.009$ & $3.16 \pm$ 0.08, PU/mg protein & 0.977 \\
\hline Modified Anson method & $0.136 \pm 0.017$ & $2.31 \pm 0.15, \mu$ mol tyrosine/mg protein per min & 0.979 \\
\hline OPA method & $0.104 \pm 0.012$ & $3.55 \pm 0.10, \mu \mathrm{mol} \mathrm{NH}_{2}$-group/mg protein per min & 0.984 \\
\hline
\end{tabular}

Ta b le 3. Kinetic parameters of casein hydrolysis, catalyzed by peptidase from Bacillus thuringiensis, determined by the Eadie-Hofstee method

\begin{tabular}{|c|c|c|c|}
\hline $\begin{array}{l}\text { Caseinolytic } \\
\text { activity assay }\end{array}$ & $K_{\mathrm{m}}, \mathrm{g} / \mathrm{l}$ & $V_{\max }$ & $\mathrm{R}^{2}$ \\
\hline Kunitz method & $0.084 \pm 0.011$ & $3.17 \pm 0.08, \mathrm{PU} / \mathrm{mg}$ protein & 0.956 \\
\hline Modified Anson method & $0.12 \pm 0.015$ & $2.22 \pm 0.10, \mu \mathrm{mol}$ tyrosine/mg protein per min & 0.950 \\
\hline OPA method & $0.109 \pm 0.014$ & $3.59 \pm 0.11, \mu \mathrm{mol} \mathrm{NH}{ }_{2}$-group/mg protein per min. & 0.953 \\
\hline
\end{tabular}

Ta b le 4. Kinetic parameters of casein hydrolysis, catalyzed by peptidase from Bacillus thuringiensis, determined by the Cornish-Bowden-Eisenthal method

\begin{tabular}{l|c|l}
\hline \multicolumn{1}{c|}{ Caseinolytic activity assay } & $K_{\mathrm{m}}, \mathrm{g} / \mathrm{l}$ & \multicolumn{1}{c}{$V_{\max }$} \\
\hline Kunitz method & $0.128 \pm 0.023$ & $3.23 \pm 0.06, \mathrm{PU} / \mathrm{mg}$ protein \\
Modified Anson method & $0.111 \pm 0.010$ & $2.15 \pm 0.02, \mu \mathrm{mol}$ tyrosine/mg protein per min \\
OPA method & $0.139 \pm 0.024$ & $3.59 \pm 0.11, \mu \mathrm{mol} \mathrm{NH}_{2}$-group/mg protein per min \\
\hline
\end{tabular}

\section{КІНЕТИКА ГІДРОЛІЗУ КАЗЕЇНУ ЗА ДОПОМОГОЮ НОВОї \\ ПЕПТИДАЗИ Вacillus thuringiensis var. israelensis}

\section{О. В. Севастьянов ${ }^{1}$ Ю. А. Шестеренко ${ }^{1}$, О. А. Рижак 1 , I. I. Романовська 1 , Н. А. Дзюблюк², Л. Д. Варбанецьь}

${ }^{1}$ Фізико-хімічний інститут ім. О. В. Богатського НАН України, Одеса;

${ }^{2}$ Інститут мікробіології і вірусології ім. Д. К. Заболотного НАН України, Київ; e-mail: romairina@gmail.com

Дослідження кінетики дії ензимів здійснюють, використовуючи рівняння Міхаеліса-Ментен і різні форми його лінеаризації, однак кожен 3 методів має свої переваги і недоліки, тому їх порівняння для визначення кінетики нових ензимів є актуальним. Метою цієї роботи було вивчення кінетичних особливостей гідролізу казеїну новою пептидазою Bacillus thuringiensis var. israelensis IMB B-7465 за допомогою різних методів лінеаризації рівняння МіхаелісаМентен із використанням декількох способів визначення активності ензиму. Встановлено задовільне узгодження значень кінетичних констант, одержаних методами Лайнуївера-Берка, Хейнса, Іді-Хофсті, Корніш-Боуден-Ейзенталя. Оптимальним для визначення $K_{\mathrm{m}} \mathrm{i} V_{\max } \epsilon$ метод Лайнуївера-Берка. Метод дослідження казеїнолітичної активності за допомогою о-фталевого діальдегіду (о-ФДА) порівняно з модифікованим методом Ансона і Кунітца дозволяє вірогідніше визначити $V_{\max }$ реакції.

К л юч о в і слов а: гідроліз казеїну, кінетика, методи лінеаризації, визначення активності, пептидаза, Bacillus thuringiensis var. israelensis. 


\section{References}

1. Dorra G, Ines K, Imen BS, Laurent C, Sana A, Olfa T, Pascal C, Thierry J, Ferid L. Purification and characterization of a novel high molecular weight alkaline protease produced by an endophytic Bacillus halotolerans strain CT2. Int J Biol Macromol. 2018; 111: 342-351.

2. Alici EH, Arabaci G. A novel serine protease from strawberry (Fragaria ananassa): Purification and biochemical characterization. Int J Biol Macromol. 2018; 114: 1295-1304.

3. Devi SG, Fathima AA, Sanitha M, Iyappan S, Curtis WR, Ramya M. Expression and characterization of alkaline protease from the metagenomic library of tannery activated sludge. J Biosci Bioeng. 2016; 122(6): 694-700.

4. Yoshii K, Ogasawara M, Yamamoto Y, Inouye K. Activating effects on trypsin, $\alpha$-chymotrypsin, and lipase and inhibitory effects on $\alpha$-amylase and $\alpha$-glucosidase as provided by low-molecularweight compounds in the water extract of the earthworm Eisenia fetida. Enzyme Microb Technol. 2018; 118: 20-29.

5. Verma M.K., Pulicherla K.K. Broad substrate affinity and catalytic diversity of fibrinolytic enzyme from Pheretima posthumous Purification and molecular characterization study. Int J Biol Macromol. 2017; 95: 1011-1021.

6. Beynon RJ, Bond JS. Proteolytic enzymes: a practical approach. Oxford university press, 2000. 340 p.

7. Stohniy EM, Chernyshenko VO, Nidialkova NA, Rebriev AV, Varbanets LD, Hadzhynova VE, Chernyshenko TM, Kolesnikova IM, Lugovskoy EV. Mapping of residues of fibrinogen cleaved by protease II of Bacillus thuringiensis var. israelensis IMV B-7465. Ukr Biochem J. 2016; 88(Spec Iss.): 79-86.

8. Pat. 96195UA. Bacterial strain of Bacillus thuringiensis var. israelensis- producer of the extracellular collagenase. Nidialkova N.A., Varbanets L.D., Ivanitsa V.O. Publ. 26.01.2015, Bul. No 2. Ukrainian.

9. Koltukova NV, Vaskivnyuk VT. Selection of methods for isolating the proteolytic complex from Bacillus mesentericus 316m for deep cultivation. Microbiol J. 1980; 42(2): 245-248.

10. Laemmli UK. Cleavage of structural proteins during the assembly of the head of bacteriophage T4. Nature. 1970; 227(5259): 680-685.

11. Petrova IS, Vintsyunaite MM. Determination of the proteolytic activity of enzyme preparates of microbiological origin. Prikl Biokhim Mikrobiol. 1966; 2(3): 322-327. (In Russian).

12. Hartree EF. Determination of protein: a modification of the Lowry method that gives a linear photometric response. Anal Biochem. 1972; 48(2): 422-427.

13. Kunitz M. Crystalline soybean trypsin inhibitor. II. General properties. J Gen Physiol. 1947; 30(4): 291-310.

14. Church FC, Swaisgood HE, Porter DH, Catignani GL. Spectrophotometric assay using o-phthaldialdehyde for determination of proteolysis in milk and isolated milk proteins. J Dairy Sci. 1983; 66(6): 1219-1227.

15. Keleti T. Basic enzyme kinetics. M.: Mir, 1990. 348 p. (In Russian).

16. Taylor J. An Introduction to error theory. M.: Mir, 1985. $272 \mathrm{p}$.

17. Walls D, Loughran ST. Protein Chromatography: Methods and Protocols, Methods in Molecular Biology. New York: Humana Press: Springer; 2007, vol. 681. 426 p.

18. Ibrahim AS, Al-Salamah AA, El-Badawi YB, ElTayeb MA, Antranikian G. Detergent-, solventand salt-compatible thermoactive alkaline serine protease from halotolerant alkaliphilic Bacillus sp. NPST-AK15: purification and characterization. Extremophiles. 2015; 19(5): 961-971.

19. Iqbal A, Hakim A, Hossain MS, Rahman MR, Islam K, Azim MF, Ahmed J, Assaduzzaman M, Hoq MM, Azad AK. Partial purification and characterization of serine protease produced through fermentation of organic municipal solid wastes by Serratia marcescens A3 and Pseudomonas putida A2. J Genet Eng Biotechnol. 2018; 16(1): 29-37. 